\author{
Arnaldo BORDONI*
}

\title{
A new species of glyptomeroid Lathrobium from Campania, Italy
}

\author{
(Coleoptera, Staphylinidae)
}

\begin{abstract}
Riassunto: Una nuova specie di Lathrobium gliptomeroide della Campania, Italia (Coleoptera, Staphylinidae).
Lathrobium petruzzielloi sp. n. dalla Grotta degli Angeli (Monti Picentini, Monte Cervialto, Acerno, Campania, Italia), la specie ritrovata più a sud della penisola italiana di questo gruppo, è qui descritta e raffrontata con L. angelae Bordoni \& Magrini, 1996 della Grotta dei Diavoli (Monti del Matese, Letino, Caserta, Campania, Italia). Viene presentata una mappa di distribuzione del gliptomeroide Lathrobium Gravehorst, 1802 negli Appennini italiani. La seguente sinonimìa è convalidata: Lathrobium Gravenhorst, $1802=$ Glyptomerus H. Müller, 1856.
\end{abstract}

\begin{abstract}
Lathrobium petruzzielloi sp. n. from Grotta degli Angeli (Picentini Mounts, Cervialto Mount, Acerno, Campania, Italy), the most southern species in the Italian peninsula of this group, is described and compared with L. angelae Bordoni \& Magrini, 1996 from Grotta dei Diavoli (Matese Monts, Letino, Caserta, Campania, Italy). A map of the distribution of the glyptomeroid Lathrobium Gravehorst, 1802 in the Italian Apennines is presented. The following synonymy is validated: Lathrobium Gravenhorst, $1802=$ Glyptomerus H. Müller, 1856 .
\end{abstract}

Key words: Coleoptera, Staphylinidae, Lathrobium petruzzielloi, Campania, new species.

\section{INTRODUCTION}

Luigi Petruzziello, an enthusiastic speleologist and entomologist, sent me for study a glyptomeroid Lathrobium collected in a cave of Campania (Southern Italy) representing the southernmost locality of these depigmented, anophthalmous or microphthalmous and apterous Staphylinids. In describing this new species of great interest, I take the opportunity to summarize the distribution of the group in the Apennines. I present this distribution in a map (Fig. 1): L. doderoi Abeille, 1900 (medium filled square), L. zoiai Briganti, 1980 (large triangle), L. straneoi Schatzmayr \& Koch, 1934 (empty small square), L. andreinii Schatzmayr \& Koch, 1934 (small arrow), L. rosai Bordoni, 1985 (empty triangle), L. garioi Bordoni, 1984 (halo); L. magrinianum Bordoni, 1986 (small filled inverted triangle), L. degiovannii Bordoni, 2005 (empty star), L. apenninum Baudi, 1870 (small filled square), $L$. magrinii Bordoni, 2012a (empty circle), L. colacurcioi Bordoni \& Magrini, 2016 (square within square), L. bastianinii Bordoni \& Magrini, 2011a, (empty large inverted triangle), L. bramantii Bordoni, 2012 (filled triangle pointing right), L. assingi Bordoni, 1997 (large arrow), L. etruscum Piccioli, 1871 (large filled star), L. castellinii Bordoni, 1979 (square within cir- cle), L. lottii Holdhaus, 1923 (small filled circle), L. cirocchii Bordoni, 1987 (large filled circle), L. vignai Bordoni, 1998 (large filled inverted triangle), L. genganum Bordoni, 1972 (small arrow), L. volscum Bordoni, 2010 (open inverted rhombus), L. lacustre Bordoni, 1972 (triangle within circle), L. livatense Bordoni, 1985 (large open square), L. oblitum Pace, 1977 (small open inverted triangle), L. franzinii Bordoni, 1985 (small filled star), L. maginii Bordoni, 1972 (filled rhombus), L. auruncum Bordoni \& Magrini 2011 (filled triangle pointing left), L. angelae Bordoni \& Magrini, 1996 (large empty triangle), L. petruzzielloi sp. n. (large filled square). Nine other species of this group occur in northern Italy, so 38 glyptomeroid Lathrobium are now known from Italy.. Most of these Staphylinids are restricted to single localities, and even more widespread species such as $L$. maginii in Mugello and L. etruscum in the Vallombrosano-Pratomagno area are limited to small areas.

Since there are no external characters or relating to the edeagus to justify the existence of the subgenus Glyptomerus H. Müller, 1856 and because in some catalogs (e.g. Smetana, 2004; Schulke \& Smetana, 2015) the species of this group but not all (for example L. vignai missing and $L$. assingi related

*Arnaldo Bordoni, Museo di Storia Naturale dell’Università di Firenze, Sezione di Zoologia “La Specola”, Via Romana 17, 50125 Firenze (FI), Italy. E-mail arnaldo.bordoni@fastwebnet.it 


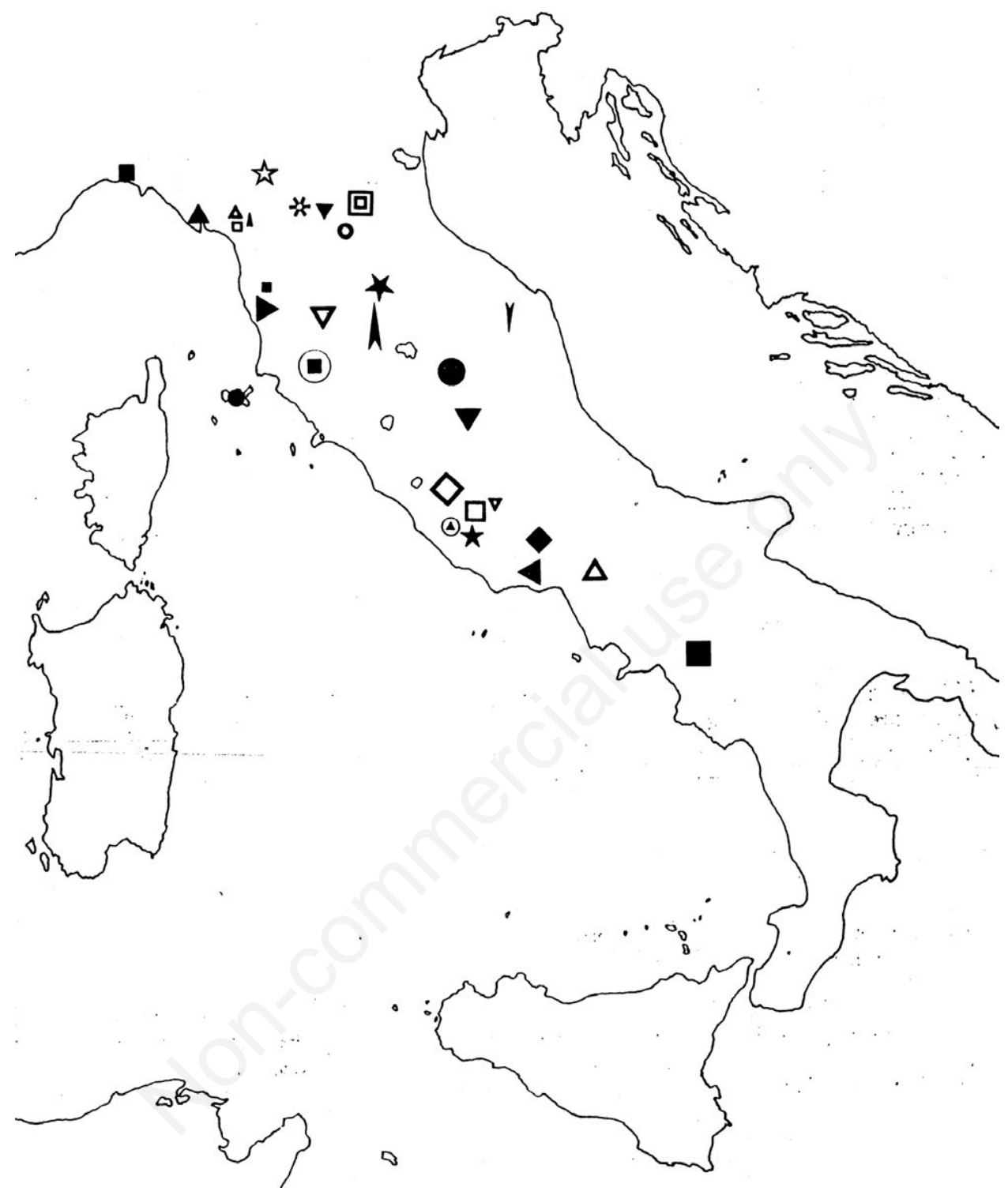

Fig. 1. Distribution of the glyptomeroid Lathrobium in the Italian Apennines. L. doderoi Abeille, 1900 (medium filled square), L. zoiai Briganti, 1980 (large triangle), L. straneoi Schatzmayr \& Koch, 1934 (empty small square), L. andreinii Schatzmayr \& Koch, 1934 (small arrow), L. rosai Bordoni, 1985 (empty triangle), L. garioi Bordoni, 1984 (halo); L. magrinianum Bordoni, 1986 (small filled inverted triangle), L. degiovannii Bordoni, 2005 (empty star), L. apenninum Baudi, 1870 (small filled square), L. magrinii Bordoni, 2012a (empty circle), L. colacurcioi Bordoni \& Magrini, 2016 (square within square), L. bastianinii Bordoni \& Magrini, 2011a, (empty large inverted triangle), L. bramantii Bordoni, 2012 (filled triangle pointing right), L. assingi Bordoni, 1997 (large arrow), L. etruscum Piccioli, 1871 (large filled star), L. castellinii Bordoni, 1979 (square within circle), L. lottii Holdhaus, 1923 (small filled circle), L. cirocchii Bordoni, 1987 (large filled circle), L. vignai Bordoni, 1998 (large filled inverted triangle), L. genganum Bordoni, 1972 (small arrow), L. volscum Bordoni, 2010 (open inverted rhombus), L. lacustre Bordoni, 1972 (triangle within circle), L. livatense Bordoni, 1985 (large open square), L. oblitum Pace, 1977 (small open inverted triangle), L. franzinii Bordoni, 1985 (small filled star), L. maginii Bordoni, 1972 (filled rhombus), L. auruncum Bordoni \& Magrini 2011 (filled triangle pointing left), L. angelae Bordoni \& Magrini, 1996 (large empty triangle), L. petruzzielloi sp. n. (large filled square). 
to the subgenus Lathrobium s. str.) are still attributed to the subgenus Glyptomerus, I consider finally appropriate to validate the synonymy Lathrobium Gravenhorst, 1802 = Glyptomerus H. Müller, 1856, proposed by Coiffait (1972).

For the sake of completeness I recall that Coiffait (1972) initially proposed the synonym between Glyptomerus and Lathrobium and subsequently, without explanations, collected some species under the subgenus Glyptomerus (Coiffait, 1982). Later Piva (1995) confirmed this latter proposal by suggesting characters I had shown to be insubstantial as present/absent both in glyptomeroid Lathrobium both in Lathrobium s. str. (Bordoni, 1997).

\section{TAXONOMY}

\section{Lathrobium petruzzielloi $\mathrm{sp} . \mathrm{n}$.}

Material eXAmined. Holotype ${ }_{+}:$Italy, Campania, Cervialto Mount, Grotta degli Angeli n. $588 \mathrm{Cp} / \mathrm{SA}$ (Picentini Mounts, Acerno, Salerno), 1075 mt, L. Petruzziello leg. 18.VII.2015 (with traps) (coll. Bordoni, Firenze).

DESCRIPTION. Body (Fig. 2) length about $11 \mathrm{~mm}$; length from anterior margin of head to posterior margin of elytra about $5 \mathrm{~mm}$. Body of the usual light brown coloration. Similar to L. angelae Bordoni \& Magrini, 1996 from Grotta dei Diavoli (Matese Mountains, Campania) from which it differs in the following characters: body smaller (in L. angelae $12 \mathrm{~mm}$ long, $5.5 \mathrm{~mm}$ from anterior margin of head to posterior margin of elytra) and narrower; in particular head visibly narrower, not roundish as in L. angelae, with less rounded sides (in $L$. angelae head almost orbicular with very rounded sides); surface of head with more evident, very fine and dense, transverse micro-striation, with smaller and more dense punctation. Eyes totally obsolete, represented by a smaller macula without ommatidia (a few ommatidia in L. angelae). Pronotum a little shorter, slender, visibly narrower than in L. angelae, sub-rectangular and not dilated forward as in L. angelae, with more oblique anterior angles. Surface with more dense and smaller punctures. Elytra longer and narrower, not dilated posteriad, with more obsolete humeral angles. Surface of elytra and abdomen with similar punctation.

Posterior margin of the sixth visible sternite with a small median emargination. In the other species of this group of Lathrobium the posterior margin of the sixth female visible sternite is rounded or with a more or less protruberent median lobule.

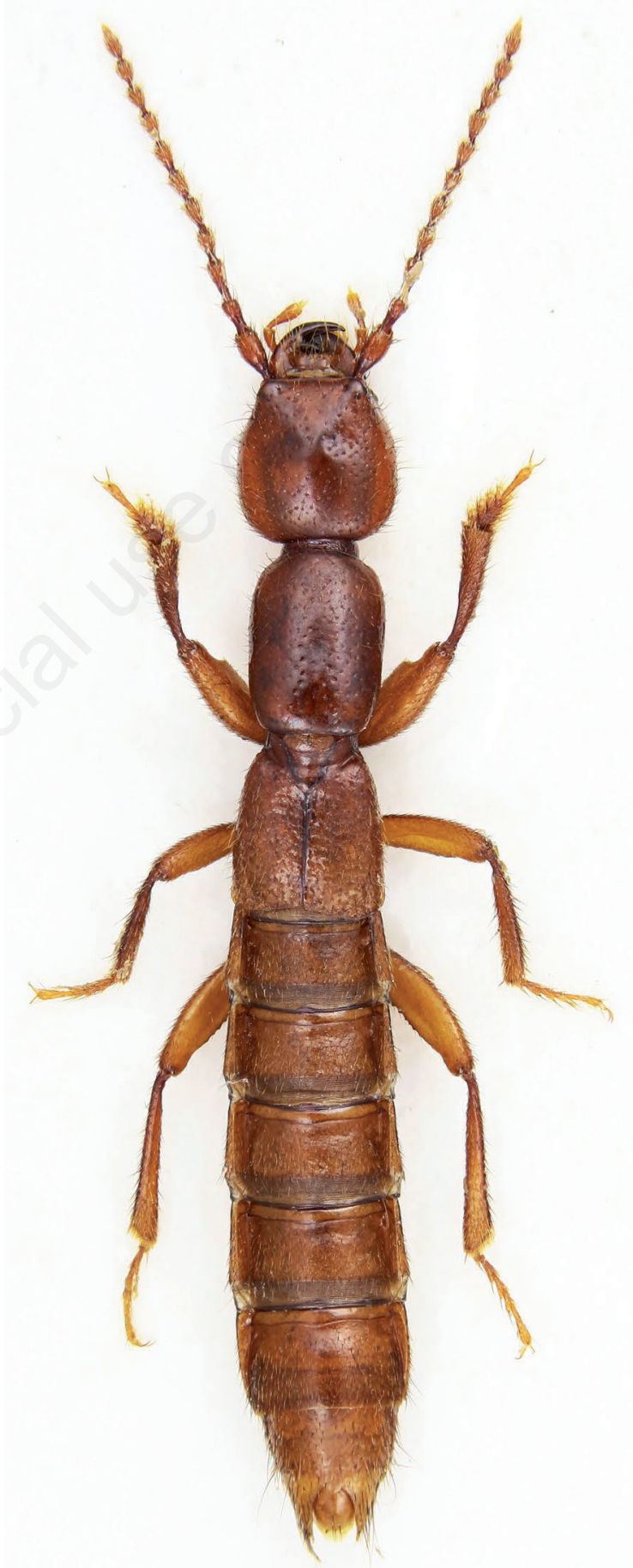

Fig. 2. Habitus of Lathrobium petruzzielloi sp. n. (photo S. Cuoco). 
Male unknown.

Etymology. Patronymic. The species is dedicated to our friend and colleague Luigi Petruzziello.

DisTRIBUTION. The species in known only from the type locality.

REMARKS. The Grotta degli Angeli (Fig. 3) is located on the southern slope of Mount Cervialto, just off the
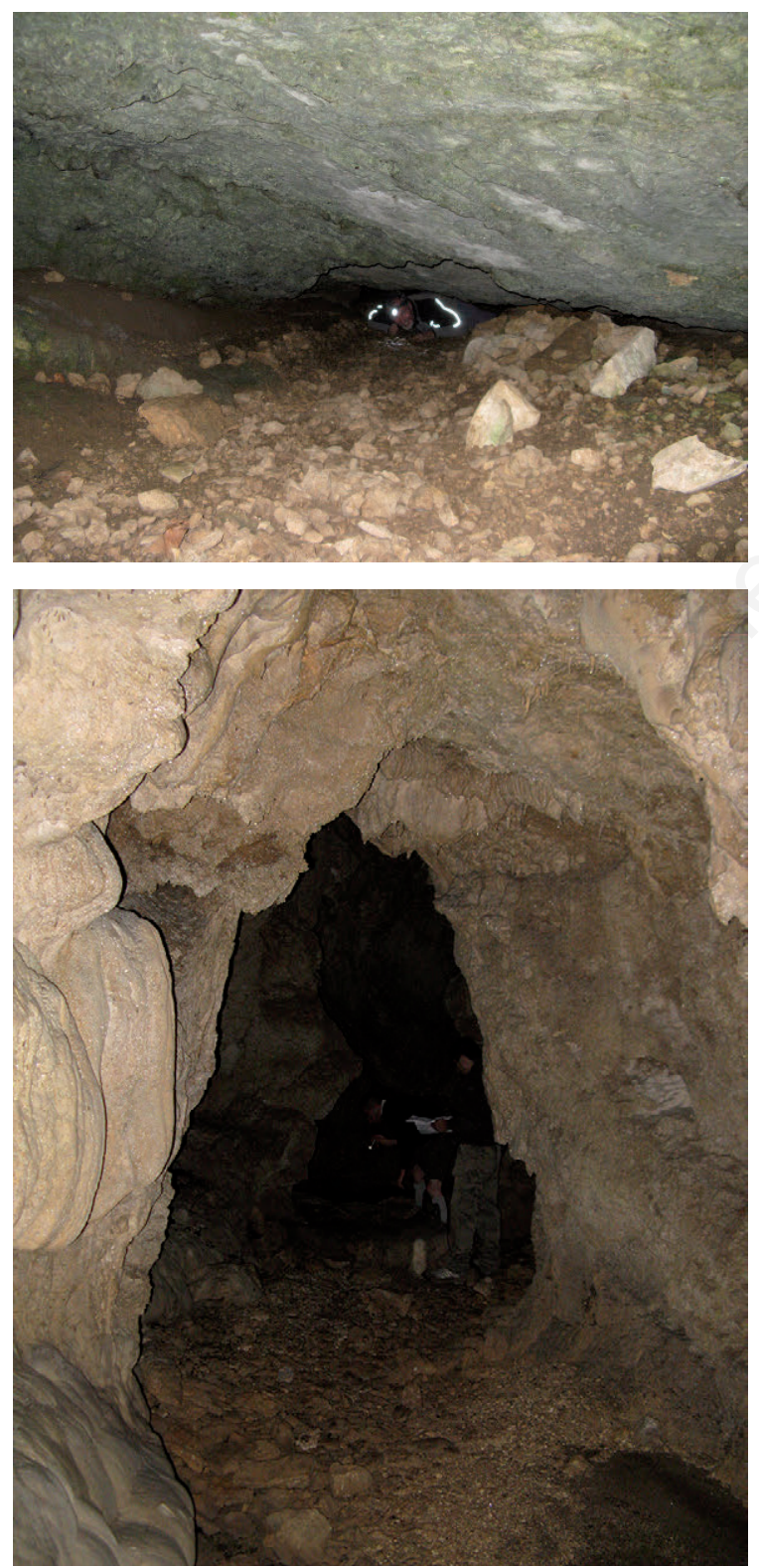

Fig. 3. Grotta degli Angeli (photo L. Petruzziello).
Strazzatrippa cave, in "Piano Cupone" locality (Fig. 4) (typographic tablets F. 186 I NE Monte Cervialto). According to some (Giulivo et al., 1988; Russo et al., 2005) the Grotta Strazzatrippa and Grotta degli Angeli constitute a single karst channel along approximately 550 meters connected by a very narrow currently inaccessible siphon, so they may be considered to be two separate caves. Grotta degli Angeli is characterized by a different environment, with a planimetric development of 380 meters (compared to 95 meters in Strazzatrippa) and is a classic example of an endorheic basin that stands out among the rugged slopes of the surrounding mountains. The cave is located on a small limestone relief in a collapsed doline. The genesis of these cavities is very probably linked to the continuousmoulding activity of the drainage waters of Mount Cervialto, as evidenced by the counterslope profiles carved into idromorphic shapes resembling scallops (Giulivo et al., 1. c.). These data may explain why few endogeous beetles were collected in the cave (apart a species of Bathysciola and a new species of Anemadus: see later), but rather elements not strictly related to the caves. The glyptomeroid Lathrobium are not in fact properly endogean but hypogean and live under deeply sunken stones and in the ground of the woods, although certain species may be found in caves.

The southern slope of Mount Cervialto where the cave is located is covered by a vast beech forest (Fig. 5) mixed with sycamore maple (Acer pseudoplatanus L.), Neapolitan alder (Alnus cordata (Loisel.)) and holly bushes (Ilex aquifolium L.), typical plants of wetlands.

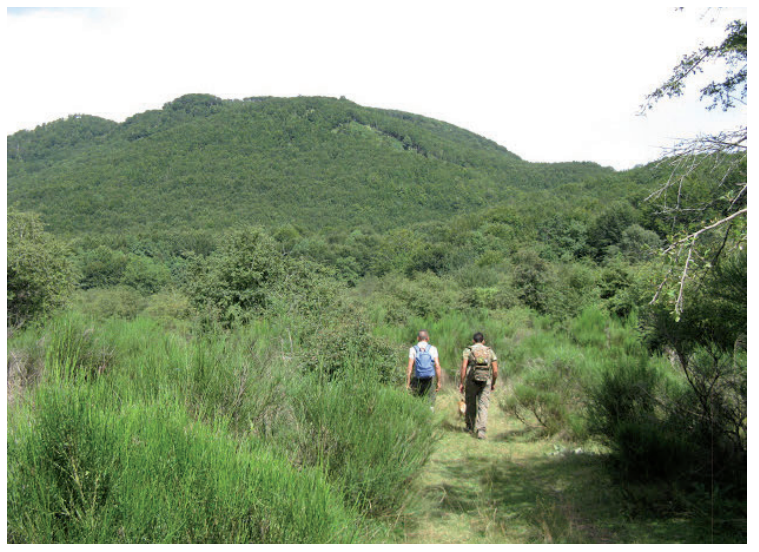

Fig. 4. Piano Cupone locality (photo L. Petruzziello). 


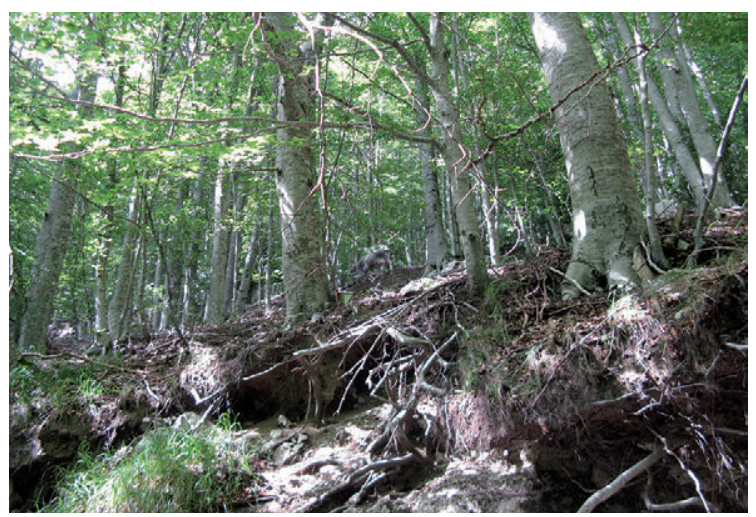

Fig. 5. Beechwood of Cervialto Mount (photo L. Petruzziello).

Lathrobium petruzzielloi was collected in a trap in the Grotta degli Angeli. Despite repeated visits and trapping over the years no other specimen was collected, even under rocks around the entrance of the cave.

The following Coleoptera were collected in this place, inside the cave and at its entrance: Carabus preslii neumeyeri Schaum, 1856; Cychrus italicus Bonelli, 1810; Pterostichus micans Heer, 1841; Laemostenus acutangulus (Schauffus, 1862); Trechus arthuri Moravec \& Lompe 2003, T. obtusus lucanus Focarile, 1949; Ocys harpaloides (Serville, 1821); Nebria kratteri Dejean, 1831 (Carabidae); Choleva sturmi Brisout, 1863; Catops subfuscus Kellner, 1846 and a new species of Anemadus Reitter, 1885 that will be described by P. M. Giachino (Cholevidae); Leptinus testaceus Müller, 1817 (Platypsyllinae) (for the references of these families see I. Löbl \& A. Smetana, 2003 and Perreau M., 2004). All the cited species, apart the Cholevidae in my collection, are preserved in the Petruzziello collection.

A separate note deserves the collection (L. Petruzziello 27.XII.2014-28.XII.2015) of many specimens of the Cholevidae Bathysciola partenii Ruffo, 1947, until now known only from the type locality:
Grotta degli Sportiglioni, Avella, Avellino, in Campania (see also Capolongo et al., 1974). This cave spreads over 120 meters at the base of the southern slope of Mt Spadafora, in a valley of the Clanio torrent and for its biospeleological features is one of the most interesting in Campania. Bathysciola partenii was also collected in the Grotta del Caprone, Montella, Avellino, $850 \mathrm{~m}$, L. Petruzziello 22.XII.2014 and Grotta Strazzatrippa, L. Petruzziello 8.VII.2015-17.VIII. 2015: unpublished data.

The comparison with $L$. angelae from Cave dei Diavoli (Matese mounts, Letino, Caserta, Campania) comes from the fact that this is the glyptomeroid $\mathrm{La}$ trobium closer geographically, located about $80 \mathrm{~km}$ as the crow flies. L. petruzzielloi is currently the southernmost species of the group in the Italian peninsula.

These considerations and the highlighted external characters lead me to describe the species albeit on the basis of a female.

Note. The name of the cave seems to be due to the fact that it was discovered by two speleologists from Campania, related to each other and both named Angelo, so the caves from which the two mentioned species come were given the fanciful names Devils' and Angels'.

\section{ACKNOWLEDGEMENTS}

I wish to thank the following colleagues: Silvio Cuoco (Livorno) for the nice photograph of the species; Pier Mauro Giachino (Settore Fitosanitario Regionale, Torino) for the identification of part of Cholevidae, and Luigi Petruzziello (Ramedello, Brescia) who for years has conducted entomological research in the caves of Campania, collected the species, generously donated the specimen to me, and provided copious information and photographs of the habitat. My thank also to Guillaume de Rougemont (Oxford) for the English control, Leonardo Latella (Museo civico di Storia naturale, Verona) and Stefano Zoia (Dipartimento di Scienze della Terra-Geofisica, Milano) for some information.

\section{REFERENCES}

AbeILle de Perrin E., 1900 - Description de deux Staphylinides nouveaux circumméditerranéens (Col.). Bulletin de la Socièté Entomologique de France: 203-205.

Baudi di Selve F., 1870 - Coleopterorum messis in insula Cypro et Asia minore ab Eugenio Truqui congregatae recensito: de Europaeis notis quibusdam additis. Pars prima. Berliner Entomologische Zeitschrift, 8: 195-233.

Bordoni A., 1972 - I Glyptomerus dell'Appenino centrale e settentrionale e descrizione di nuove specie (Col. Staphylinidaae). Redia, 53: 347-371. 
Bordoni A., 1979 - Studi sui Paederinae. II Intorno ad alcuni Glyptomerus della Toscana. Redia, 62: 13-16.

Bordoni A., 1984 - Note su alcuni Lathrobium Gravenhorst gliptomeroidi dell'Appennino con descrizione di una nuova specie (Coleoptera, Staphylinidae). Bollettino dell'Associazione Romana di Entomologia, 37 (1982): 19-28.

Bordoni A., 1985 - Tre nuove specie di Lathrobium s. str. gliptomeroidi dell'Appenino centro-settentrionale (Col. Staphylinidaae). Giornale italiano di Entomologia, 2, 9: 265-274.

Bordoni A., 1986 - Un nuovo Lathrobium Gravh. gliptomeroide del Lago di Pratignano nell'Appennino Modenese (Coleoptera, Staphylinidae). Redia, 69: 657-663.

Bordoni A., 1987 - Un nuovo Lathrobium Gravenhorst gliptomeroide del Monte Subasio (Umbria) (Col. Staphylinidae). Bollettino della Società entomologica italiana, 119, 2: 94-98.

Bordoni A., 1998 - Una nuova specie di Lathrobium ipogeo dell'Italia centrale (Col. Staphylinidae). Fragmenta entomologica, 30, 1: 93-103.

Bordoni A., 1997 - Lathrobium assingi n. sp. ipogea della Toscana e note su L. lottii Holdhaus dell'isola d'Elba. Bollettino della Società entomologica italiana, 129: 99-107.

Bordoni A., 2005 - Un nuovo Lathrobium del Monte Orocco in Emilia (Coleoptera, Staphylinidae). Bollettino dell'Associazione Romana di Entomologia, 60, 1-4: 3-6.

Bordoni A., 2010 - Lathrobium volscum n. sp. from Lupone Mountain in Latium, Italy (Coleoptera Staphylinidae). Redia, 93: $107-108$.

Bordoni A., 2012 - Lathrobium bramantii sp. n. gliptomeroide della Versilia (Toscana, Massa Carrara) (Insecta Coleoptera Staphylinidae). Quaderno di Studi e Notizie di Storia Naturale della Romagna, 35: 151-155.

Bordoni A., 2012a - Lathrobium magrinii sp. n. from the cave "Grotta dell'Arnale" in Latium. Italy (Coleoptera Staphylinidae). Redia, 95: 39-41.

Bordoni A., Magrini P., 1996 - Due nuove specie di Staphylinidae ipogei dell'Italia centrale (Coleoptera). Redia, 79, 2: 177185.

Bordoni A., Magrini P., 2011 - A new glyptomeroid species of Lathrobium from the Aurunci Mountains, Latium (Coleoptera Staphylinidae). Bollettino della Società entomologica italiana, 143, 1: 15-17.

Bordoni A., Magrini P., 2011a - Lathrobium bastianinii n. sp. of the limestone caves of Piteccio (Tuscany, Italy). Bollettino dell'Associazione Romana di Entomologia, 66, 1-4: 1-4.

Bordoni A., Magrini P., 2016 - Lathrobium colacurcioi n. sp. from Emilia-Romanga (Italy) (Coleoptera, Staphylinidae). Giornale italiano di Entomologia, 14 (61): 405-408.

BRIGANTI L., 1980 - Lathrobium (s. str.) zoiai n. sp. della Liguria orientale (Coleoptera Staphylinidae Paederinae). Bollettino della Società entomologica italiana, 112, 9-10: 175-177.

Capolongo D., Cantilena S., Panasci R., 1974 - Specie cavernicole di Campania. Annali dell'Istituto e Museo di Zoologia dell'Università di Napoli, 20 (1973/74): 33-213.

CoIfFAit H., 1972 - Paederinae nouveaux ou mal connus de la Région paléarctique occidentale. Nouvelle Revue d'Entomologie, 2, 2: $131-150$.

CoIfFAIT H., 1982 - Coléoptères Staphylinidae de la Région paléarctique occidentale. IV. Sous famille Paederinae, Tribu Paederini I (Paederi, Lathrobii). Nouvelle Revue d'Entomologie, suppl., 12, 4, 440 pp.

Huldhaus K., 1923 - pp. 77-144. In: Elenco dei coleotteri dell'isola d'Elba, con studi sul problema della Tirrenide. Memorie della Società Entomologica Italiana, 2: 77-175.

GiUlivo L., N. NicASTRO, A. SANTO, 1988 - Alcune considerazioni sulle grotte di Strazzatrippa e degli Angeli (Monti Picentini-Avellino). L’Appennino meridionale. Annuario del Club Alpino Italiano, Sezione di Napoli, Napoli Castel dell'Ovo: 37-41.

Gravenhorst J. L. C., 1802 - Coleoptera Microptera Brunsviciensia nec non exoticorum quotquot exstant in collectionibus entomologorum Brunsviciensium in genera familias et species distribuit. Brunsuigae, Carolus Reichardt, $206 \mathrm{pp}$.

Löbl I., A. Smetana, 2003 - Catalogue of the Palaearctic Coleoptera, Vol. I, Carabidae, Stentrup, Apollo Books, 819 pp.

PACE R., 1977 - Quindici nuove specie di Stafilinidi ipogei dell'Italia centro-meridionale. Redia, 60: 125-177.

Perreau M., 2004 - pp. 134-203 - In I. Löbl \& A. Smetana (editors): Catalogue of Palaearctic Coleoptera, Vol. 2. Stentrup, Apollo Books, 942 pp.

Piccioli F., 1871 - Descrizione di due nuove specie di coleotteri italiani. Bollettino della Società Entomologica Italiana, 2 (1870): 306-314.

PIVA E., 1995 - Descrizione di una nuova specie di Lathrobium Gravenhorst, 1802 del Vicentino e considerazioni sul valore del sottogenere Glyptomerus Müller, 1856 (Coleoptera Staphylinidaae). Bollettino della Società entomologica italiana, 126 , 3: $211-224$.

RuFfo S., 1947 - Una nuova specie cavernicola di Bathysciola Jeann. (s. str.) (Col. Catopidae) dell'Italia meridionale. Bollettino della Società dei Naturalisti, Napoli, 56, 5: 3 pp.

Russo N., Del Prete S., Giulivo I., Santo A., 2005 - Grotte e Speleologia della Campania. Federazione Speleologica campana, Regione Campania. E. Sellino Ed., Avellino, 624 pp.

SchatzmaYR A., Koch C., 1934 - Due nuovi Glyptomerus delle Alpi Apuane (Col. Staph.). Bollettino della Società Entomologica Italiana, 66: 259-266.

SchÜlke M., Smetana A., 2015 - Catalogue of Palaearctic Coleoptera. In: LöBL I, LöBL D (eds). Vol. 1-2, Brill, Leiden-Boston, 1702 pp. pp. 304-1134 